\title{
Tratamiento conservador de las fracturas del cóndilo: Evaluación radiológica y clínica
}

\section{Conservative treatment of condyle fractures: Radiological and clinical evaluation}

\author{
A. Wassouf, R. Verdeja, K.W. Grätz
}

Resumen: Las ventajas del tratamiento quirúrgico de las fracturas del proceso condilar hasta la fecha han despertado controversia en la literatura. El tratamiento conservador es el método de elección en nuestra clínica, por lo tanto, el propósito de este estudio es evaluar los resultados obtenidos en un grupo de nuestros pacientes, seleccionados y aleatorizados, que recibieron un tratamiento conservador de fracturas del proceso condilar.

Se evaluaron las intervenciones terapéuticas entre 1997 y 2000 en 30 pacientes (18 varones, 12 mujeres, edad media de 25 años) con fracturas del cóndilo y un tiempo de seguimiento medio de 12 meses. Se incluyó un total de 35 fracturas del cóndilo en este estudio. El tratamiento utilizado fue la fijación maxilomandibular (FMM), que se aplicó durante 2 semanas en las fracturas unilaterales y durante 3 a 4 semanas en las fracturas bilaterales. Se realizó una evaluación radiológica inicial del ángulo del proceso condilar fracturado y del acortamiento de la rama ascendente. Se evaluaron las exploraciones clínicas y radiológicas a intervalos regulares (6 semanas y 3,6 y 12 meses).

Cinco pacientes presentaron fracturas bilaterales; todos con luxación anterior. En el grupo de las fracturas unilaterales, 12 pacientes presentaron luxación anterior (valor medio $23^{\circ}$ ) en la radiografía panorámica. Trece pacientes presentaron luxación posterior (valor medio $10^{\circ}$ ). En la proyección posteroanterior se observó la luxación medial en 12 fracturas (valor medio 14²) y luxación lateral en 4 fracturas (valor medio $6^{\circ}$ ). El acortamiento de la rama ascendente alcanzó un valor medio de 5,40 mm. Se logró una funcionalidad y movilidad satisfactorias en todos los pacientes tratados. Las secuelas postraumáticas fueron el chasquido de la articulación temporomandibular (ATM) (5 de 29), la desviación de la boca al abrirse (14 de 27), la

Departamento de Cirugía Craneomaxilofacial, Hospital Universitario de Zurich, Suiza

\section{Correspondencia:}

Dr. Raúl Verdeja

Boulevard de Pérolles 20

1700 Fribourg - Suiza

raulverdeja@hotmail.com
Abstract: Benefits of surgical treatment for condylar fractures are to date discussed controversially in the literature. As conservative treatment is the method of choice in our clinic, the purpose of this study is to evaluate the outcomes of a randomised selected group of our patients who received conservative treatment for condylar fractures.

The acts of 30 patients ( 18 males, 12 females, mean age of 25 years) treatment for condylar fractures between 1997 and 2000 with a mean follow up time of 12 months have been assessed. A total of 35 condyle fractures were included in this study. The treatment applied was maxillo-mandibular fixation (MMF) for 2 weeks on unilateral fractures, and 3 - 4 weeks on bilateral fractures. Initial radiological evaluation of the broken condyles angulations and shortening of the ascending ramus was performed. Clinical and radiological examinations were assessed in regular intervals (6 weeks, 3, 6 and 12 months).

5 patients presented bilateral fractures; all of them had anterior dislocation. In the unilateral fracture group 12 presented anterior dislocations (mean value of $23^{\circ}$ ) on the panoramic $x$-ray. 13 cases presented posterior dislocation (mean value of $10^{\circ}$ ). On the (PA) projections 12 fractures presented medial dislocation (mean value of $14^{\circ}$ ), 4 presented lateral dislocation (mean value of $6^{\circ}$ ). Ascending ramus shortening reached a mean value of $5.40 \mathrm{~mm}$. Satisfactory function and mobility were observed in all the treated cases. Posttraumatic sequels as TMJ clicking (5 of 29), deviation by mouth opening (14 of 27), reduction of lateral movements and protrusion (in 15 of 29) and finally mouth opening ranged 30 to $60 \mathrm{~mm}$. In conclusion, conservative treatment of condylar fractures is a safe treatment method avoiding surgery with predictable good results. Degree of the displacement or ascending ramus shortening didn't prevent obtaining good results in this study.

Key words: Fractures; Maxillo-mandibular fixation; Radiological dislocation. 
reducción de los movimientos laterales y de la protrusión (15 de 29) y finalmente un rango de apertura de la boca de 30 a $60 \mathrm{~mm}$.

Para concluir, el tratamiento conservador de las fracturas del proceso condilar es un método de tratamiento seguro que evita la cirugía y produce fiablemente buenos resultados. El grado de desplazamiento o de acortamiento de la rama ascendente no precluyó obtener buenos resultados en este estudio.

Palabras clave: Fracturas; Fijación maxilomandibular; Luxación radiológica.

Recibido: 10-09-2003

Aceptado: 06-10-2004

\section{Introducción}

La fractura del proceso condilar se considera una de las fracturas más frecuentes de la mandíbula. El tratamiento de esta clase de fracturas ha despertado polémica en la literatura. Algunos prefieren el tratamiento conservador, ${ }^{2,6}$ y otros el tratamiento quirúrgi$\mathrm{CO}^{3-9}$ guiados por la filosofía de que el acortamiento de la rama ascendente y el desplazamiento del proceso condilar fracturado puede originar limitación funcional de la articulación temporomaxilar (ATM). ${ }^{8}$

La reducción abierta de estas fracturas y el uso de miniplacas o tornillos de esponjosa producen buenos resultados radiográficos y funcionales, pero conllevan el riesgo de la resorción del cóndilo, que podría ser más problemático que las posibles complicaciones del tratamiento conservador. ${ }^{5}$

En nuestro departamento, el tratamiento conservador de estas fracturas, sin tomar en cuenta el acortamiento de la rama o la posición del cóndilo, es el tratamiento de elección. Hemos obtenido resultados muy favorables, como demuestra este estudio de seguimiento de 12 meses.

Este artículo presenta un estudio retrospectivo de 30 pacientes seleccionados aleatorizados con 35 fracturas condilares tratadas de forma conservadora. El acortamiento de la rama y la posición del proceso condilar fracturado no fueron factores limitantes para el tratamiento conservador en este grupo.

\section{Material y método}

Se estudiaron 30 casos documentados por radiología y clínica (18 varones, 12 mujeres) de fractura condilar tratados entre 1997 y 2001. La edad de los pacientes se comprendió entre los 15 y 65 años, con una media de 25 años. El tiempo de seguimiento medio de los pacientes fue 1 año.

Se incluyó en este estudio un total de 35 fracturas condilares repartidas en dos grupos: un grupo de 25 fracturas unilaterales y un grupo de 10 fracturas bilaterales en 5 pacientes.

Nueve pacientes tuvieron fracturas asociadas de la mandíbula.

Se dividieron las fracturas del proceso condilar en 5 niveles siguiendo a Köhler (1951):

\section{Introduction}

Condyle fractures are considered to be one of the most common fractures of the mandible. Treating this kind of fractures is controversially discussed in the literature. Some prefer to treat it conservatively ${ }^{2,6}$ and some others prefer the surgical treatment ${ }^{3-9}$ according to the philosophy which says that shortening of the ascending ramus and displacement of the broken condyle has potentiality of (TMJ) functional limitation ${ }^{8}$.

Open reduction of condyle fracture and using of mini plates or lag screws, even they give good radiographs and functional results but they also have the potentiality of condyle resorption which could be more problematic than possible complications of the conservative treatment. ${ }^{5}$

In our department the conservative treating of these fractures without consideration to the ramus shortening or broken condyle position is the treatment of choice since we have very positives results as shown on these 12 months follow up study.

This article presents a retrospective study on 30 randomised selected patients who had 35 conservatively treated condylar fractures. Ramus shortening and the position of the fractured condyle were not limiting factors for conservative treatment in this group.

\section{Materials and methods}

30 radiological and clinical documented cases (18 males, 12 females) of condylar fractures between 1997-2001. Age of the patients ranged between 15 and 65 years with a mean age of 25 years. The mean follow up time of the patients was 1 year.

A total number of 35 condyle fractures divided in two groups were included in this study. A unilateral group of 25 fractures and bilateral fractures group of 10 fractures in 5 patients.

9 patients had additional fractures in the mandible.

Condyle fractures were divided into 5 levels as follow according to Köhler (1951):

1. Inter-capsular fracture or high condyle fracture.

2. High neck fracture.

3. Neck fracture.

4. Low neck fracture.

5. High ramus fracture.

The treatment was 2 Weeks Maxillo-Mandibular fixation for unilateral and 3 to 4 Weeks for bilateral fractures independent from the localisation as shown on figure 1. Our goal was to show the result and compare it according to these different types of fractures.

After applying of the wire splint described by Obwegeser (1952) a maxillo-mandibular fixation (MMF) was applied for 2 weeks for the unilateral fractures, and 3-4 weeks for the bilateral fractures. 
1. Fractura intercapsular o fractura condilar alta.

2. Fractura alta de cuello.

3. Fractura de cuello.

4. Fractura baja del cuello.

5. Fractura alta de rama.

Se trataron las fracturas condilares unilaterales con 2 semanas de fijación maxilomandibular (FMM) y las fracturas bilaterales con 3 a 4 semanas de FMM independientemente de la localización según se demuestra en la Fig. 1. Nuestro objetivo era demostrar el resultado y compararlo según los diversos tipos de fractura.

Después de colocar un fijador de alambre descrito por Obwegeser (1952), se aplicó fijación maxilomandibular (FMM), que se mantuvo durante 2 semanas en las fracturas unilaterales y durante 3 a 4 semanas en las fracturas bilaterales.

Se evaluó el acortamiento de la rama ascendente y la luxación del proceso condilar fracturado únicamente en el grupo de las fracturas unilaterales, como han descrito Lindqvist y lizuka. ${ }^{1}$ No se realizaron estas mediciones en el grupo de las fracturas bilaterales debido a la ausencia de un lado de referencia. El acortamiento de la rama ascendente y la luxación anterior o posterior se evaluaron en la radiografía panorámica (Fig. 2).

La altura de la rama es la distancia perpendicular entre la línea de la mandíbula (LM) y una línea tangencial entre el punto superior del cóndilo (CA) medido desde la línea de la rama (LR) en los lados con fractura y sin fractura desde el punto A hasta el punto D. La reducción en la altura de la rama es la diferencia en la longitud del lado con fractura y el lado sin fractura, independientemente del factor de ampliación por la proyección.

El ángulo de luxación $(\alpha)$ anteroposterior se definió entre la línea de la rama (LR) y el reborde lateral del cóndilo en el lado de la fractura (LC). El ángulo $\alpha$ es el ángulo entre la línea de la rama (LR) y el reborde posterior del cóndilo (LC) en el lado intacto; en la luxación anterior se sumó el valor de $\alpha$ al ángulo medido en el lado de la fractura. En la luxación posterior se restó el valor de $\alpha$ del ángulo medido en el lado de la fractura (Fig. 2).

La luxación medial o lateral del proceso condilar fracturado se evaluó en la proyección anteroposterior del cefalograma. Se evaluó la angulación del cóndilo como el ángulo entre una línea mediocondilar (LMC) y una línea que discurre a lo largo de la placa cortical lateral $(P C L)$ de la rama mandibular. El ángulo $\beta$ representa el ángulo en el lado de la fractura. La luxación en el lado de la frac-
Assessing of ascending ramus shortening and dislocation of the fractured condyle were performed only for the unilateral group as described by Lindqvist \& lizu$k a^{1}$. In the bilateral group these measurement were not possible to assess due to the absence of the reference side. Ascending ramus shortening and anterior or posterior dislocation were performed on the panoramic X-Ray (Fig. 2) Height of the Ramus is the perpendicular distance between the mandibular line (ML) and a tangential line to the superior point of the condyle (CA) measured along the ramus line (RL) on the fractured and non-fractured sides from point $(A)$ to point (D). Reduction of the ramus height is represented by the difference in length between the fractured and non-fractured sides without regards for the enlargement factor due to the projection. Dislocation angle $(\alpha)$ in the anterior-posterior direction was defined between the (RL) line and the lateral border of the broken condyle $(\mathrm{CL})$. The angle $(\alpha)$ presents the angle between $(R L)$ and the posterior border of the condyle $(C L)$ on the intact side, in the anterior dislocation the value of $(\alpha)$ was added to the measured angle on the fractured side. In the posterior dislocation the value of $(\alpha)$ was subtracted from the measured angle on the fractured side (Fig. 2).

Dislocation of the broken condyle toward the medial or lateral directions was assessed on the anterior posterior cephalogram projection (PA). Angulation of the condyle is assessed as the angle between a mid-condylar line (MCL) and a line along the lateral cortical plate (LCP) of the mandibular ramus. The angle $(\beta)$ presents the angle on the brocken side. Dislocation of the fractured side is presented by the difference between the angles on the fractured and non-fractured sides. The angle $\left(\beta^{\prime}\right)$ presents the intact side angle between (MCL) and (LCP), it was subtracted in case of medial dislocation (Fig. 3) and was added in case of the lateral dislocation.

Only 17 patients had the (PA) radiographs. Clinical and radiological examinations were assessed in regular intervals 
tura equivale a la diferencia entre los ángulos en los lados con fractura y sin fractura. El ángulo $\beta$ ' equivale al ángulo entre LMC y PCL en el lado intacto; este ángulo se resta en el caso de la luxación medial (Fig. 3) y se suma en el caso de la luxación lateral.

Sólo 17 pacientes tuvieron radiografías posteroanteriores. Se evaluaron las exploraciones clínicas y radiológicas a intervalos regulares de 6 semanas y 3, 6 y 12 meses.

\section{Resultados}

En el grupo de las fracturas condilares unilaterales (GUL), 8 de los 25 pacientes tuvieron fracturas adicionales de la mandíbula inferior. Se evaluó la angulación del proceso condilar desplazado en la radiografía panorámica en todos los 25 pacientes. En el grupo de las fracturas bilaterales (GBL) no se evaluó la angulación debido a la ausencia de un lado de referencia. El acortamiento de la rama se evaluó únicamente en el GUL por la misma razón. Doce cóndilos presentaron luxación anterior con un valor medio de $23^{\circ}$ y un rango de $1^{\circ}$ a $139^{\circ}$. Los otros 13 cóndilos presentaron luxación posterior con un valor medio de $10^{\circ}$ y un rango de $1^{\circ}$ a $17^{\circ}$.

Fue posible evaluar la luxación mesolateral en sólo 15 pacientes del GUL que tuvieron radiografías de la proyección AP. Doce procesos condilares presentaron una angulación medial con un valor medio de $14^{\circ}$ y un rango de $2^{\circ}$ a $37^{\circ}$. Los otros 3 cóndilos presentaron luxación distal con un valor medio de $8^{\circ}$ y un rango de $2^{\circ}$ a $19^{\circ}$.

Las figuras 4, 5, 6 y 7 de abajo recogen los valores anteriores en detalle.

Se detectó acortamiento de la rama en el lado de la fractura (Fig. 2); los resultados se aclaran en el diagrama 8.

Se distribuyeron las clases de fracturas en estos 30 pacientes como sigue:

- Fracturas intercapsulares: 1 fractura.

- Fracturas altas del cuello: 1 fractura.

- Fracturas del cuello: 6 fracturas.

- Fracturas del cuello bajo: 14 fracturas.

- Fracturas altas de la rama: 3 fracturas. La duración de la fijación maxilomandibular (FMM) fue de 2 a 3 semanas

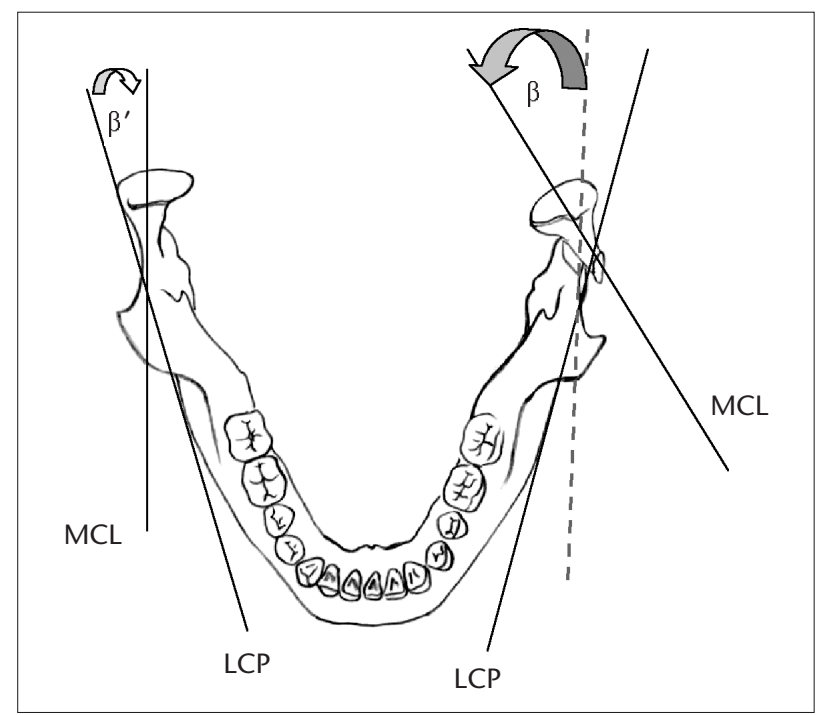

Figura 3. Luxación medial $(\beta)$ y el método de evaluar la angulación del proceso condilar fracturado en la radiografía posteroanterior. La línea de puntos indica la posición original del cóndilo en el lado de la fractura.

Figure 3. Medial dislocation ( $\beta$ ), and method of assessing the angulation of the broken condyle on the Posterio-Anterior radiograph. The dotted line refers to the original position of the broken condyle.

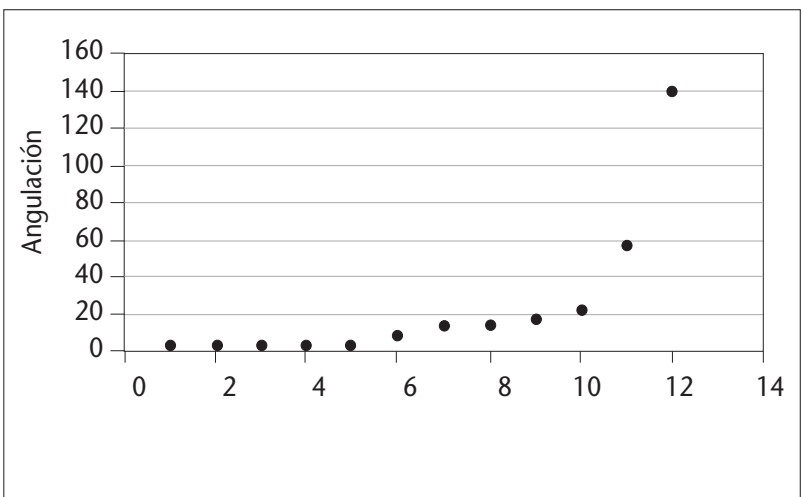

Figura 4. Distribución de ángulos de luxación anterior ( $N=12$ cóndilos).

Figure 4. Anterior dislocation angles distribution ( $N=12$ condyles).

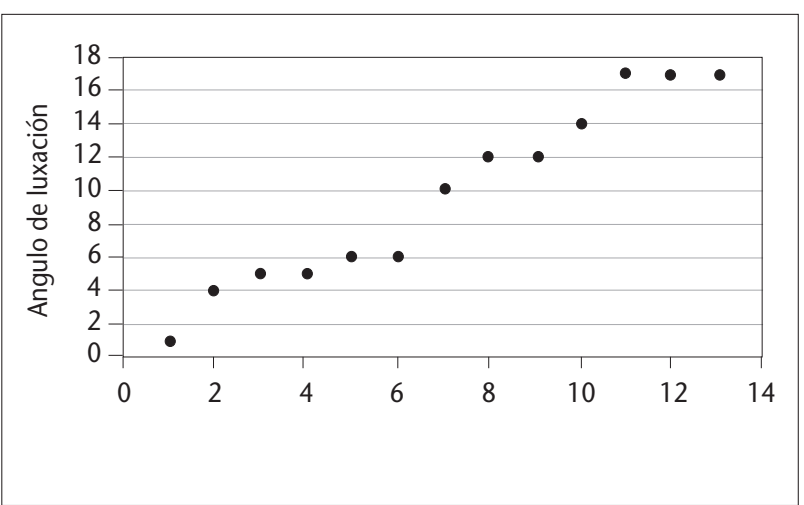

Figura 5. Distribución de ángulos de luxación posterior ( $\mathrm{N}=13$ cóndilos).

Figure 5. Posterior dislocation angles distribution ( $N=13$ condyles). of 6 weeks, 3, 6 and 12 months.

\section{Results}

In the unilateral condyle fractures group (ULG) among 25 patients 8 had additional fractures in the lower jaw. The angulation of the dislocated condyle was assessed on the panoramic $X$-Ray for all these 25 patients. In bilateral fractures group (BLG) assessing the angulation was not possible due to the absence of a reference side. Ramus shortening was assessed only for the (ULG) also for the same reason. 12 condyles presented anterior dislocations with a mean value of $23^{\circ}$ ranging between $1^{\circ}-139^{\circ}$. The other 13 condyles presented Posterior dislocation with a mean value of $10^{\circ}$ ranging between $1^{\circ}-17^{\circ}$.

Mesial-lateral dislocation was possible to assess only for 15 patients in the (ULG) who had the (AP) projections. 12 condyles presented medial angulation with a mean value of $14^{\circ}$ ranging between $2^{\circ}-37^{\circ}$. The other 3 condyles presented distal dislocation with a mean value of $8^{\circ}$ ranging between $2^{\circ}-19^{\circ}$.

The figures 4, 5, 6, and 7 below show the previous values in details.

Ramus shortening on the broken side is detected (Fig. $2)$, the results are clarified in the figure 8.

Fractures kinds distribution in these 30 patients was as follow:

- Inter capsular fractures: 1 fracture.

-High collum fractures: 1

fracture. 
en el GUL y de 3 a 4 semanas para el GBL.

En el GUL el tiempo medio de FMM fue 17 días, con un intervalo de 14 a 23 días. La diferencia se debió al caso y a la estabilidad de la oclusión de 1 a 3 días después de retirar la FMM.

En todos los pacientes del GBL, la duración de la FMM fue 21 días. En ambos grupos, la funcionalidad y la oclusión evidenciaron una alteración mínima, sin que ningún paciente se quejara en la última visita de seguimiento. Ninguno de los pacientes precisó una corrección posterior de la oclusión mediante la división sagital de la rama.

El valor medio de apertura de la boca fue $46 \mathrm{~mm}$, con un rango de 30 a 60 $\mathrm{mm}$ en 28 pacientes; se perdieron 2 pacientes para el seguimiento porque no se encontraron datos sobre el valor de la apertura de la boca.

Se evaluaron los movimientos laterales en 15 pacientes. El lado de la fractura evidenció un valor medio de $7 \mathrm{~mm}$ y el lado intacto, $8 \mathrm{~mm}$. El valor medio de la protrusión fue $5 \mathrm{~mm}$ en 11 pacientes del GUL, con un rango de 1 a $9 \mathrm{~mm}$.

Cinco de 29 pacientes manifestaron chasquido de la articulación temporomandibular (ATM); en un paciente no había información relativa a este tema en el archivo.

Se observó desviación al abrir la boca en 14 de 27 pacientes; en 3 pacientes no había información referente a esta desviación.

Dos pacientes demostraron dolor leve a la palpación en el lado de la fractura; indicaron que no era significativo y no afectaba la función de la ATM.

Ninguno de los pacientes incluidos en este estudio evidenció una alteración de la oclusión que afectaba la función de la ATM en cualquiera de los lados; ninguno de los pacientes precisó una división de la rama para corregir la oclusión.

No se comunicó ningún caso de desarrollo de maloclusión o agravación de los síntomas.

\section{Discusión}

El tratamiento conservador de las fracturas del proceso condilar es la norma seguida en nuestro departamento. Al evitar la intervención quirúrgica se logran grandes ventajas y buenos resulta-

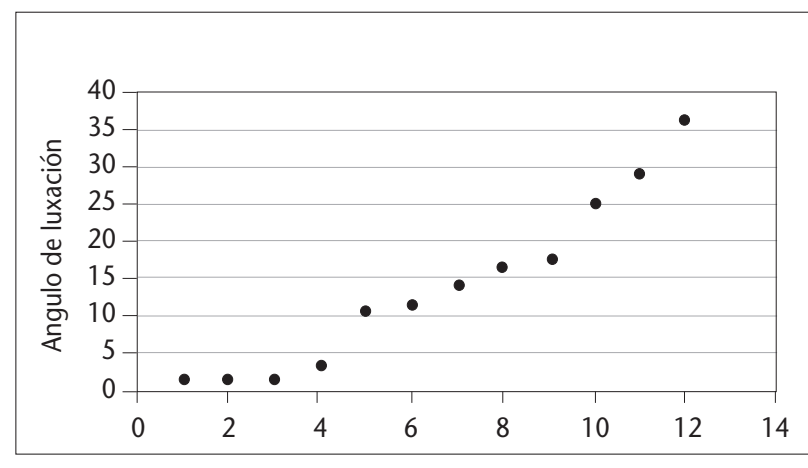

Figura 6. Distribución de ángulos de luxación medial ( $N=12$ cóndilos).

Figure 6. Medial dislocation angles distribution ( $N=12$ condyles).

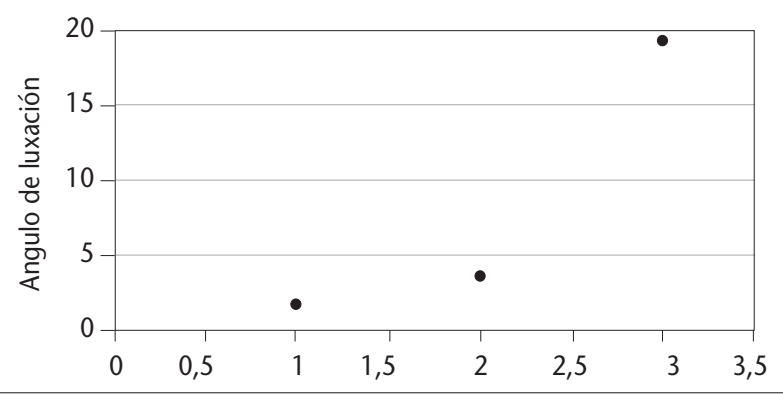

Figura 7. Distribución de ángulos de luxación lateral $(N=13$ cóndilos).

Figure 7. Lateral dislocation angles distribution ( $N=3$ condyles).

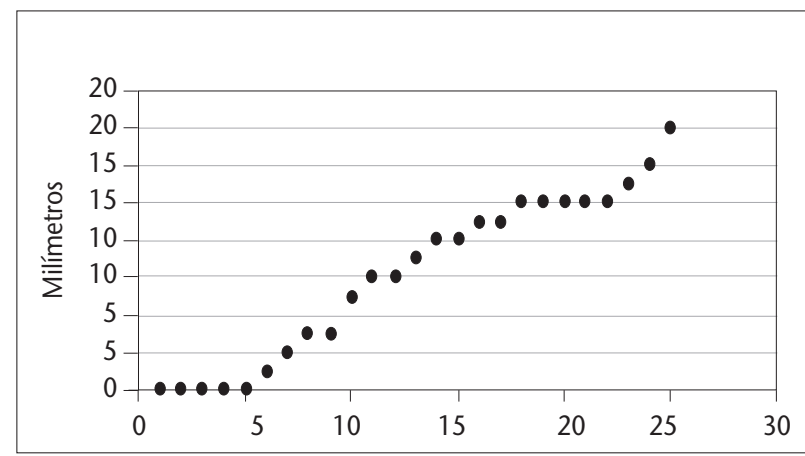

Figura 8. Acortamiento de rama en el GUL $(\mathrm{N}=25)$.

Figure 8. Ramus shortening in the ULG $(N=25)$.
- Collum fractures: 6 fractures.

- Low collum fractures: 14 fractures.

-High ramus fractures: 3 fractures.

Maxillo-mandibular fixation (MMF) time was 2-3 weeks for the (ULG), and 3-4 weeks for the (BLG).

In the (ULG) the mean time of the (MMF) was 17 days ranging between 14-23 days. The difference existed due to the case and occlusal stability after 1 and 3 days after the removal of the (MMF).

In all the (BLG) the (MMF) time was 21 days. In both groups the function and occlusion showed minimal disturbance, without individual complaints of the patient, at the last controlling. None of the cases necessitate later occlusal correction via ramus sagital splitting.

Mouth opening mean value was $46 \mathrm{~mm}$ and ranged between 30 and $60 \mathrm{~mm}$ for 28 patients, 2 patients were dropped out because no existing data about mouth opening value could be found.

Lateral movements were assessed for 15 patients, the broken side showed a mean value of $7 \mathrm{~mm}$ and the intake side showed $8 \mathrm{~mm}$. Protrusion mean value was $5 \mathrm{~mm}$ for 11 patients of the (ULG) and ranged between 1- $9 \mathrm{~mm}$.

5 patients of 29 showed clicking in the Temporo-mandibular joint (TMJ), one case had no information in the file about this subject.

Deviation when opening the mouth was found in 14 patients of 27 since for 3 patients it was not mentioned if they showed deviation when opening the mouth or not.

Two patients showed slight pain when palpating the broken side, they informed that it was not significant and doesn't affect the function of the (TMJ).

No case in this study showed occlusal disturbance affecting the function of the (TMJ) on any side, no case needed 
dos en esta clase de fracturas. El acortamiento de la rama crea una situación asimétrica en la rama ascendente pero, según E. Ellis III, ${ }^{4}$ se han observado tres clases de adaptación en los pacientes tratados de forma conservadora.

1. La adaptación del sistema neuromuscular para cambiar la biomecánica de la función mandibular y eventualmente permitir a los pacientes lograr una oclusión normal.

2. El establecimiento de una articulación temporomandibular nueva entre la mandíbula y la base del cráneo. ${ }^{7}$

3. La adaptación dentoalveolar, cuando se produce una inclinación del plano mandibular debido a una pérdida de la dimensión vertical posterior. La única manera de mantener una oclusión normal es por extrusión de los dientes anteriores y/o por intrusión de los dientes posteriores. ${ }^{4}$

Mediante estas tres adaptaciones se pueden resolver los problemas que aparezcan debido a la situación asimétrica entre el lado con fractura y el lado sin fractura. ${ }^{8}$

En una encuesta realizada para conocer las opiniones de un grupo de 120 cirujanos maxilofaciales en todo el mundo sobre el método preferido para tratar las fracturas condilares, Baker y cols. ${ }^{2}$ encontraron los resultados siguientes en función del tipo de fractura, siempre que el cóndilo fracturado estuviera desplazado y asociado con alteraciones de la oclusión.

\begin{tabular}{lcccc}
\hline Clase de fractura & Conservador & Quirúrgico & Combinación & $\begin{array}{c}\text { Sin tratamiento } \\
\text { activo }\end{array}$ \\
Unilateral & $78 \%$ & $9 \%$ & $10 \%$ & $3 \%$ \\
Bilateral & $34 \%$ & $17 \%$ & $46 \%$ & $3 \%$ \\
\hline
\end{tabular}

Los resultados anteriores indican que el tratamiento conservador aún se considera el tratamiento de elección por muchos cirujanos maxilofaciales. La preferencia por la combinación de tratamiento quirúrgico con un período de aplicación de FMM refleja las ventajas que se derivan de un período de estabilización de la oclusión con respeto a mejorar el desenlace clínico. En nuestro estudio ninguno de los pacientes precisó una división sagital de la rama más adelante o la adaptación de la oclusión debido a una alteración; se logró una oclusión estable y equilibrada en este grupo de pacientes con el tratamiento conservador. E. Ellis III y cols. ${ }^{3}$ han comunicado una oclusión más estable con el tratamiento conservador comparado a los pacientes tratados quirúrgicamente.

En 6 pacientes (4 GUL y $2 \mathrm{GBL}$ ) se detectaron síntomas como chasquidos y el dolor leve a la palpación de la AMT. Un paciente con fracturas bilaterales asociadas con acortamiento severo de las ramas en ambos lados y una marcada luxación de los dos cóndilos presentó ambos síntomas, chasquido y dolor leve a la palpación. El acortamiento de la rama en 4 de estos 6 pacientes varió entre 6 y $10 \mathrm{~mm}$, con un valor medio de $8 \mathrm{~mm}$. Ahora parece que cuando el acortamiento de la rama es superior a $8 \mathrm{~mm}$ hay más posibilidad de que se produzca chasquido y dolor a la palpación. ${ }^{8}$ Se observó desviación hacia el lado de la fractura al abrirse la boca en 13 pacientes del grupo de fracturas unilaterales con acortamiento de la rama de 0 a $14 \mathrm{~mm}$ (valor medio 5,9 mm). Ninguno de los 9 pacientes del GUL con acortamiento de la rama de menos de $5 \mathrm{~mm}$ evidenció chasquido o dolor a la palpación. Estos resultados son similares a los resultados comunicados por Silvennoinen y cols. ${ }^{8}$ En otro estudio comunicado por Konstantinovic y Dimitrijevic ${ }^{6}$ de 80 pacien- sagitale splitting of the ramus as an occlusion correction procedure.

No later open bite formation or worsening of the symptoms was reported.

\section{Discussion}

Conservative treatment for condylar fractures is the way of treatment in our department. By avoiding surgical intervention great benefits and high results can be achieved in this kind of fractures. Ramus shortening is creating an asymmetrical situation on the ascending ramus, but according to E. Ellis III three kinds of adaptation has been noticed in conservatively treated cases.

1. Adaptation within the neuromuscular system that is changing the biomechanics of the mandibular function which helps the patients to establish their normal occlusion at the end.

2. A new temporomandibular articulation is established between the mandible and the base of the skull. ${ }^{7}$

3. Dentoalveolus adaptation, when mandibular plane steeping occurs because of loos of the posterior vertical dimension, then the only way to maintain a normal occlusion is by extrusion of the anterior teeth and/or by intrusion of the posterior teeth. ${ }^{4}$

By these three adaptations the problems which can appear due to the asymmetrical situation between the broken and intact side can be over came. 8

In a survey to clarify the opinions of a group of 120 maxillofacial surgeons around the world about the preferred method to treat condyle fractures, Baker et al. ${ }^{2}$ The results were as follow according to fractures kind considering that the fractured condyle is dislocated and associated with an altered occlusion.

Type of the fracture Conservative Surgical Combination No active treatment

$\begin{array}{cccc}78 \% & 9 \% & 10 \% & 3 \% \\ 34 \% & 17 \% & 46 \% & 3 \%\end{array}$

From the schedule above it looks that the conservative treatment is still considered to be the treatment of choice for a lot of maxillofacial surgeons, also preference of combination between the surgical treatment with a period of (MMF) application refers to the benefit of a period of occlusion stabilising for better outcomes. In our study none of the patients presented needing for later ramus sagittal splitting or occlusion adjustment due to occlusal disturbance, a stable and balanced occlusion is obtained in this group of patients after conservative treatment. Better occlusion stability after conservative treatment is reported by E. Ellis III et al. ${ }^{3}$ when compared to surgical treated cases.

In 6 patients (4 ULG and 2 BLG) symptoms as clicking and slight pain when palpating the (TMJ) could be detected. One patient who had bilateral fracture associated with severe ramus shortening on both sides and heavy disloca- 
tes, de los cuales 54 pacientes recibieron tratamiento conservador y 26 se trataron quirúrgicamente, no se encontró ninguna diferencia entre los dos tratamientos. Sin embargo, las exploraciones radiográficas en el mismo grupo demostraron una posicionamiento significativamente mejor de las fracturas del proceso condilar reducidas quirúrgicamente, habida cuenta de que las fracturas tratadas de manera conservadora presentaron inicialmente menos luxación en comparación con el grupo quirúrgico.

Debido a estos resultados y a nuestra larga experiencia satisfactoria con el tratamiento conservador de las fracturas condilares por la aplicación de una FMM durante 2 a 3 semanas en las fracturas unilaterales y 3 a 4 semanas en las fracturas bilaterales, seguido por un período posterior de FMM elástica, éste es el tratamiento de elección en nuestro departamento.

\section{Conclusión}

El tratamiento conservador de las fracturas de proceso condilar por aplicación de una fijación maxilomandibular es un método terapéutico seguro que evita la cirugía y logra buenos resultados fiablemente. En las fracturas unilaterales del cóndilo realizamos FMM durante 2 a 3 semanas y durante 3 a 4 semanas en las fracturas bilaterales. Se recomienda un período corto posterior de FMM para obtener los mejores resultados. La gravedad de la luxación del proceso condilar fracturado o el acortamiento de la rama en el lado de la fractura no precluyó la obtención de resultados satisfactorios en este estudio.

\section{Bibliografía}

1. Atlas of Craniomaxillofacial Osteosynthesis. Georg Thieme Verlag, Rüdigerstrasse 14 D-70469 Stuttgart, Germany, 1999, p.p. 63-4.

2. Baker AW, McMahon J, Moos KF. Current consensus on the management of fractures of the mandibular condyle - A method by questionnaire. Int J Oral MaxiIlofac Surg 1998; 27: 258-66.

3. Ellis E III. Occlusal results after open or closed treatment of fractures of the mandibular condylar process. J Oral Maxillofac Surg 2000: 58: 260-8.

4. Ellis E III, Simon P, Throckmorton G S. Complications of mandibular condyle fractures. Int J Oral Maxillofac Surg 1998: 27: 255-7.

5. lizuka T, Lindqvest C, Hallikainen D, Mikkonen P, Paukku P. Sever bone resorption and osteoarthrosis after mini-plate fixation of high condylar fractures. A clinical and radiologic study of thirteen patients. Oral Surg 1991: 72: 400-7.

6. Konstantinovic VS, Dimitrijevic B. Surgical versus conservative treatment of unilateral condylar process fractures: clinical and radiographic evaluation of 80 patients. Int J Oral Maxillofac Surg 1992: 50: 349-53.

7. Lindahl L, Hollender L. Condylar fractures of the mandible. II. Radiographic study of remodeling processes in the tempomandibular joint. Int J Oral Surg 1997: 6: 153-65.

8. Silvennoinen $U$, Rausita AM, Lindqvist C, Oikarinen K. Occlusal and tempomandibular joint disorder in patients with unilateral condylar fracture. A prospective one- year study. Int J Oral Maxillofac Surg 1998; 27: 280-5.

9. Eckelt U. Zugschraubenosteosynthese bei Unterkiefergelenkforsatzfrakturen. Dtsch Z Mund Gesichts Chir 1991; 15: 51-7. tion of both condyles presented both symptoms, clicking and slight pain on palpation. Ramus shortening in 4 of these 6 patients ranged between $6-10 \mathrm{~mm}$ with a mean value of 8 $\mathrm{mm}$. It looks that when ramus shortening is more than 8 $\mathrm{mm}$ then the chance of clicking and pain on palpation to occur is higher. ${ }^{8}$ Deviation on opening toward the fractured side was noticed in 13 patients in the unilateral fractures group where ramus shortening ranged between 0-14 $\mathrm{mm}$ with a mean value of $5.9 \mathrm{~mm}$. None of 9 ULG patients who had ramus shortening less than $5 \mathrm{~mm}$ showed clicking or pain on palpation. These results are similar to the outcomes reported by Silvennoinen et al. ${ }^{8}$ In an other study reported by Konstantinovic and Dimitrijevic 6 on 80 patients where 54 patients received conservative treatment and 26 were treated surgically, no difference was found between the two treatments. However, the radiographic examinations of the same group showed a statistically better position of the surgical reduced condylar process fractures, taking in consideration that the conservatively treated fractures presented initially less dislocation when compared to the surgical group.

Due to these outcomes and our long satisfactory experience in treating condylar fracture in a conservative way by rigid (MMF) application for 2- 3 weeks in the unilateral fractures and 3- 4 weeks in the bilateral fractures, followed by a later period of elastic (MMF), it is still the treatment of choice in our department.

\section{Conclusion}

Conservative treatment of condylar fractures by maxillo-mandibular fixation (MMF) application is a safe treating method avoiding surgery with predictable good results. For unilateral condyle fractures we perform 2-3 weeks of MMF, and 3- 4 weeks for the bilateral fractures. Later short period of elastic MMF is recommended for enhanced results. Displacement severity of the broken condyle or ascending ramus shortening on the fractured side didn't prevent obtaining satisfactory results in this study. 